Original Research Article

\title{
Protective effect of Picrorhiza kurroa on Alzheimer's disease induced by aluminium chloride in rats
}

\author{
Somasekhar K. Reddy*, Sudheer A., Arunamma M., Likitha Sree P., Jyothirmayi E.
}

\begin{abstract}
Department of Pharmacology, Raghavendra Institute of Pharmaceutical Education and Research, Chiyyedu, Anantapuramu, Andhra Pradesh, India
\end{abstract}

Received: 10 January 2017

Accepted: 07 February 2017

\section{*Correspondence to:}

Dr. Somasekhar K. Reddy,

Email:

somu.reddyvaru@gmail.com

Copyright: (C) the author(s), publisher and licensee Medip Academy. This is an openaccess article distributed under the terms of the Creative Commons Attribution NonCommercial License, which permits unrestricted noncommercial use, distribution, and reproduction in any medium, provided the original work is properly cited.

\begin{abstract}
Background: Alzheimer's disease is a progressive neurodegenerative disorder characterized by cognitive deterioration together with declining activities of daily living and behavioural changes. The present work is aimed to investigate the effect of methanolic extract of rhizomes of Picrorhiza kurroa against aluminum chloride induced Alzheimer's disease.

Methods: Wistar rats were selected in this study and were divided into 5 groups (6 each). Group I served as normal control. Group II received aluminum chloride $(300 \mathrm{mg} / \mathrm{kg}$, P.O.). Group III and IV received ethanolic extract of Picrorhiza kurroa $(200 \mathrm{mg} / \mathrm{kg}, 400 \mathrm{mg} / \mathrm{kg}$, P.O. respectively) and inducing agent $\left(\mathrm{AlCl}_{3} 300 \mathrm{mg} / \mathrm{kg}\right.$, P.O.). Group V received rivastigmine $(0.3 \mathrm{mg} / \mathrm{kg}, \mathrm{I} . \mathrm{P}$.) and inducing agent $\left(\mathrm{AlCl}_{3} 300 \mathrm{mg} / \mathrm{kg}, \mathrm{P} . \mathrm{O}\right.$.). The rats were given respective treatment for 20 days and behavioural parameters were determined on $20^{\text {th }}$ day. After $20^{\text {th }}$ day rats were sacrificed and anti-oxidant parameters, brain acetylcholinesterase content were determined.

Results: Oral administration of ethanolic extract of Picrorhiza kurroa at doses $200,400 \mathrm{mg} / \mathrm{kg}$ body weight showed improve in behavioural parameters when compared to $\mathrm{AlCl}_{3}$ induced rats, showed increase in superoxide dismutase, catalase, reduced glutathione and decreased levels of malondialdehyde and showed decrease in brain acetylcholinesterase content when compared to $\mathrm{AlCl}_{3}$ induced rats.

Conclusions: The study clearly demonstrated the beneficial effects of Picrorhiza kurroa by improving biochemical and behavioural parameters.
\end{abstract}

Keywords: Alzheimer's disease, $\mathrm{Alcl}_{3}$, Antioxidant parameters, Behavioural parameters, Picrorhiza kurroa

\section{INTRODUCTION}

Alzheimer's disease (AD) is a neurodegenerative disorder that leads to memory loss and nerve cell death throughout the brain. ${ }^{1}$ This disorder is characterized by worsening in cognition and memory, progressive impairment in the ability to carry out activities of daily living, as well as a number of neuropsychiatric and behavioural symptoms. ${ }^{2}$ Most often, Alzheimer's disease is diagnosed in people over 65 years of age, although the less-prevalent earlyonset Alzheimer's can occur much earlier. Alzheimer's is predicted to affect 1 in 85 people globally by $2050 .^{3}$ At present, the etiology of Alzheimer's disease is still not clearly known. ${ }^{4}$ Multiple pathogenic factors, including aggregated beta-amyloid (A $\beta)$, neurofibrillary tangles (NFTS), cholinergic dysfunction and oxidative stress are involved in $\mathrm{AD}{ }^{5}$ The formation of hyper phosphorylated Tau (microtubule associated protein) in the neurons is also linked with $\mathrm{AD}^{6}{ }^{6}$ The selective deficiency of acetylcholine in $\mathrm{AD}$, has given rise to the cholinergic hypothesis which propose that a deficiency of acetyl choline is critical in the genesis of the symptoms of AD. ${ }^{7}$ Early disease shows a loss of short-term memory, inability to learn new information, mood swings, difficulty in finding words, forgetting names, frustration, hostility and irritability are common emotional features exhibited by patients with $\mathrm{AD}^{8}$ When the condition progress, additional cognitive abilities are impaired, as 
the ability to calculate, and use common objects and tools. ${ }^{9}$ The current symptomatic treatment of patients with mild to moderate AD is based on drugs such as donepezil, rivastigmine, galantamine and memantine which are associated with side effects. ${ }^{10}$ These drugs may help keep symptoms from getting worse for a limited time. To cure the disease development and progression medicinal plants and their ingredients are widely used since ancient time. ${ }^{11}$ So drugs for fundamental cure of Alzheimer's disease are not clinically available and greatly needed. ${ }^{12}$ Picrorhiza kurroa is also known as kutki. It belongs to the family Scrophulariaceae. ${ }^{13}$ Picrosides I and II are the active agents responsible for the medicinal effects of Kutki. ${ }^{14}$ It is widely used as a hepatoprotective. Picrorhiza kurroa has many medicinal benefits such as immunomodulatory, anti-allergic, antianaphylactic and anti-neoplastic activities. ${ }^{15,16}$ The flavonoid apocynin is one of the active metabolites of $\mathrm{P}$. kurroa and has been reported to attenuate Parkinson's, hypoxia and ischemia-reperfusion by its inhibitory action on NADH oxidase; expressed during oxidative stress. ${ }^{17,18}$ The primary aim of this investigation was to evaluate the anti-Alzheimer's activity of ethanolic extract of rhizomes of Picrorhiza kurroa.

\section{METHODS}

\section{Plant material}

Powder of rhizomes of Picrorhiza kurroa was obtained from Nepal region as a gift sample. It was identified and authenticated by Dr. J. Raveendra Reddy, Pharmacognosist, Raghavendra Institute of Pharmaceutical Education and Research (RIPER), Anantapuramu, Andhra Pradesh, India.

\section{Extraction procedure}

The powder $(500 \mathrm{~g})$ was soaked in 1 litre of $95 \%$ ethanol for 7 days with intermittent shaking. On $8^{\text {th }}$ day, the whole material was filtered through muslin cloth. The obtain filtrate was evaporated under water bath to obtain solid blackish-brown mass. The residue was stored at $4{ }^{\circ} \mathrm{C}$ until use.

\section{Animals}

Male albino wistar rats weighing 200-250g were used for the present study. The animals were obtained from Raghavendra enterprises, Bangalore, India. The animals were maintained under controlled conditions of temperature $\left(22 \pm 2^{\circ} \mathrm{C}\right)$, humidity $(50 \pm 5 \%)$ and $12 \mathrm{~h}$ lightdark cycles. All the animals were acclimatized for seven days before the study. They had free access to standard pellets as basal diet and water ad libitum. The study was approved by the institutional animal ethical committee (Approval no. 878/ac/05/CPCSEA/005/2016).

\section{Experimental design}

Animals were randomly divided into 5 groups of 6 animals each and they received the following treatment as follows. Group I served as normal control. Group II received aluminum chloride $(300 \mathrm{mg} / \mathrm{kg}$, P.O.). Group III and IV received ethanolic extract of Picrorhiza kurroa $(200 \mathrm{mg} / \mathrm{kg}, 400 \mathrm{mg} / \mathrm{kg}$, P.O. respectively) and inducing agent $\left(\mathrm{AlCl}_{3} 300 \mathrm{mg} / \mathrm{kg}\right.$, P.O.). Group $\mathrm{V}$ received Rivastigmine $\left(0.3 \mathrm{mg} / \mathrm{kg}\right.$, I.P.) and inducing agent $\left(\mathrm{AlCl}_{3}\right.$ $300 \mathrm{mg} / \mathrm{kg}$, P.O.). The rats were given respective treatment for 20 days and behavioural parameters were determined on $20^{\text {th }}$ day. After $20^{\text {th }}$ day rats were sacrificed and anti-oxidant parameters were determined.

\section{Behavioural study}

One week training was performed in rats in order to prepare them for behavioural study. During the training period only food and water were administered to rats. The fully trained rats were choice for the study.

\section{Locomotor activity}

Locomotor activity was performed in animals using a digital photoactometer. The ambulatory movements were recorded for a period of $10 \mathrm{~min}$ and expressed in terms of total photo beam counts for $10 \mathrm{~min}$ per animal. ${ }^{19}$

\section{Motor coordination}

Motor coordination of rats was performed by using rota rod according to the described procedure by. ${ }^{20}$

\section{Conditioned avoidance response test}

Conditioned avoidance response test in rats was performed by using the Pole climbing apparatus. ${ }^{21}$

\section{Spatial long-term memory assessment}

The spatial long-term memory of rats was assessed by using the Elevated plus-maze test. ${ }^{22}$

\section{Spatial memory assessment}

The Morris water maze (MWM) was performed under red light as described previously. ${ }^{23}$

\section{Cognitive abilities assessment}

Spontaneous alternation behaviour in the $\mathrm{Y}$-maze test is used to determine the assessment of short-term memory of animals. ${ }^{24}$

\section{Biochemical Parameters}

- Assessment of oxidative stress markers: The animals were anesthetized and sacrificed by cervical 
dislocation method; the brain was transferred to ice cold phosphate buffered saline quickly. It was blotted to free of blood, tissue fluids, weighed and chopped with surgical scalpel into fine slices. Then suspend in chilled $0.25 \mathrm{M}$ sucrose solution and quickly blotted on a filter paper and homogenized in chilled phosphate buffer to a concentration of $10 \% \mathrm{w} / \mathrm{v}$. homogenization is continued under hypotonic condition to release soluble proteins. The homogenate was centrifuged at $7000 \mathrm{rpm}$ for 25 minutes using Remi (RM-12C) high speed centrifuge. The clear supernatant was used for the determination of lipid peroxidation [LPO (nmol $\mathrm{MDA} / \mathrm{mg}$ wet tissue)], superoxide dismutase [SOD (Unit/mg wet tissue)], catalase [CAT $\left(\mu\right.$ mol $\mathrm{H}_{2} \mathrm{O}_{2}$ decomposed/mg wet tissue)], reduced glutathione $\left[\mathrm{GSH}\right.$ (nmol GSH/mg wet tissue)]. ${ }^{25}$

- Assessment of Acetylcholine esterase content: In the brain tissue homogenate, Acetylcholine esterase content was assessed according to the manufacturer's instructions.

\section{RESULTS}

\section{Statistical analysis}

The outcomes are expressed as the mean \pm SEM. Statistical evaluation was carried out by using one way analysis of variance (ANOVA) followed by Bonferroni multiple comparison test. $\mathrm{P}<0.05$ was considered to be significant.

\section{Effect of the ethanolic extract of Picrorhiza kurroa (EPK) on locomotor activity}

Table 1: Effect of ethanolic extract of Picrorhiza kurroa and rivastigmine on locomotor activity.

\begin{tabular}{|c|c|}
\hline Group & $\begin{array}{l}\text { Locomotor activity (No. } \\
\text { of counts } / 5 \mathrm{~min} \text { ) }\end{array}$ \\
\hline Normal control & $436.5 \pm 13.29$ \\
\hline Negative control & $319.2 \pm 1.72^{* * * *}$ \\
\hline EPK (200mg/kg) & $333.9 \pm 4.84^{\mathrm{ns}}$ \\
\hline EPK (400mg/kg) & $407.0 \pm 21.40^{\# \#}$ \\
\hline Rivastigmine $(0.3 \mathrm{mg} / \mathrm{kg})$ & $451.9 \pm 17.35^{\# \# \#}$ \\
\hline
\end{tabular}

The results in Table 1 showed significant decrease in locomotor activity in rats treated with $\mathrm{AlCl}_{3}$ when compared to normal control rats. Treatment of rats with ethanolic extract of Picrorhiza kurroa at dose $400 \mathrm{mg} / \mathrm{kg}$ significantly increased the locomotor activity when compared to negative control rats.

\section{Effect of the ethanolic extract of Picrorhiza kurroa (EPK) on motor coordination}

The results in Table 2 showed significant decrease in fall of time in rats treated with $\mathrm{AlCl}_{3}$ when compared to normal control animals. Treatment of rats with ethanolic extract of Picrorhiza kurroa at dose 200, 400mg/kg significantly increased the fall of time when compared to negative control rats in dose dependent manner.

Table 2: Effect of ethanolic extract of Picrorhiza kurroa and rivastigmine on motor coordination.

\begin{tabular}{|c|c|}
\hline Group & $\begin{array}{l}\text { Rota rod test (Fall of } \\
\text { time in sec) }\end{array}$ \\
\hline Normal control & $14.37 \pm 0.250$ \\
\hline Negative control & $5.320 \pm 0.310^{* * * *}$ \\
\hline EPK $(200 \mathrm{mg} / \mathrm{kg})$ & $13.78 \pm 0.398^{\mathrm{m \#}}$ \\
\hline EPK (400mg/kg) & $15.08 \pm 0.603^{\# \# \#}$ \\
\hline Rivastigmine & $16.54 \pm 1.078^{\# \# \#}$ \\
\hline
\end{tabular}

All values are expressed mean \pm SEM. ${ }^{* * *} \mathrm{P}<0.001$ compared with normal control, \#\#\#P<0.001 compared with negative control respectively.

\section{Effect of the ethanolic extract of Picrorhiza kurroa (EPK) on conditioned avoidance response}

Table 3: Effect of ethanolic extract of Picrorhiza kurroa and rivastigmine on conditioned avoidance response.

\begin{tabular}{|c|c|}
\hline Group & Time taken to climb pole (sec) \\
\hline Normal control & 0 \\
\hline Negative control & $155 \pm 2 * * *$ \\
\hline EPK $(200 \mathrm{mg} / \mathrm{kg})$ & $135 \pm 3^{\# \#}$ \\
\hline EPK $(400 \mathrm{mg} / \mathrm{kg})$ & $131 \pm 2^{\# \# \#}$ \\
\hline Rivastigmine & $128 \pm 1^{\# \# \#}$ \\
\hline
\end{tabular}

The results in Table 3 showed significant increase in time taken to climb the pole in rats treated with $\mathrm{AlCl}_{3}$ when compared to normal control animals. Treatment of rats with ethanolic extract of Picrorhiza kurroa at dose 200, $400 \mathrm{mg} / \mathrm{kg}$ significantly decreased in time taken to climb the pole when compared to negative control rats in dose dependent manner.

Effect of the ethanolic extract of Picrorhiza kurroa (EPK) on spatial memory using elevated plus maze

Table 4: Effect of ethanolic extract of Picrorhiza kurroa and rivastigmine on spatial memory.

\begin{tabular}{|c|c|}
\hline Group & $\begin{array}{l}\text { Elevated plus maze test } \\
\text { (Transfer of latency in secs) }\end{array}$ \\
\hline Normal control & $23.16 \pm 1.365$ \\
\hline Negative control & $42.01 \pm 0.650^{* * * *}$ \\
\hline EPK $(200 \mathrm{mg} / \mathrm{kg})$ & $17.78 \pm 1.525^{\mathrm{ns}}$ \\
\hline EPK (400mg/kg) & $33.62 \pm 3.233^{\# \# \#}$ \\
\hline Rivastigmine & $47.12 \pm 1.034^{\text {\#\# }}$ \\
\hline
\end{tabular}


The results in Table 4 showed significant increase in transfer of latency of rats treated with $\mathrm{AlCl}_{3}$ when compared to normal control animals. Treatment of rats with ethanolic extract of Picrorhiza kurroa at dose 200, $400 \mathrm{mg} / \mathrm{kg}$ significantly decreased in transfer of latency when compared to negative control rats in dose dependent manner.

\section{Effect of the ethanolic extract of Picrorhiza kurroa (EPK) on spatial memory using morris water maze}

Table 5: Effect of ethanolic extract of Picrorhiza kurroa and rivastigmine on spatial memory using water maze.

\begin{tabular}{|ll|}
\hline Group & $\begin{array}{l}\text { Water maze test (Swim } \\
\text { latency in sec) }\end{array}$ \\
\hline Normal control & $20.00 \pm 1.22$ \\
\hline Negative control & $38.73 \pm 1.39^{* * *}$ \\
\hline EPK $(200 \mathrm{mg} / \mathrm{kg})$ & $22.10 \pm 0.73^{\# \#}$ \\
\hline EPK $(400 \mathrm{mg} / \mathrm{kg})$ & $19.20 \pm 0.62^{\# \# \#}$ \\
\hline Rivastigmine & $17.15 \pm 0.54^{\text {\#\# }}$ \\
\hline All values are expressed mean \pm SEM. $* * * \mathrm{P}<0.001$ compared with
\end{tabular}
normal control, \#\#\#P<0.001 compared with negative control.

The results in Table 5 showed significant increase in swim latency of rats treated with $\mathrm{AlCl}_{3}$ when compared to normal control animals. Treatment of rats with ethanolic extract of Picrorhiza kurroa at dose 200, 400mg/kg significantly decreased in swim latency when compared to negative control rats in dose dependent manner.
Effect of the ethanolic extract of Picrorhiza kurroa (EPK) on cognitive abilities using Y-Maze

Table 6: Effect of ethanolic extract of Picrorhiza kurroa and rivastigmine on cognitive abilities using Y-maze.

\begin{tabular}{|ll|}
\hline Group & $\begin{array}{l}\text { Y- maze test (Time to reach } \\
\text { previsited arm in sec) }\end{array}$ \\
\hline Normal control & $25 \pm 2.12$ \\
\hline Negative control & $47 \pm 5.25^{\text {*** }}$ \\
\hline EPK $(200 \mathrm{mg} / \mathrm{kg})$ & $35 \pm 3.32^{\# \# \#}$ \\
\hline EPK $(400 \mathrm{mg} / \mathrm{kg})$ & $30 \pm 2.91^{\# \# \#}$ \\
\hline Rivastigmine & $28 \pm 1.98^{\# \# \#}$ \\
$\begin{array}{l}\text { All values are expressed mean } \pm \text { SEM. } * * * \mathrm{P}<0.001 \text { compared with } \\
\text { normal control \#\#\#P<0.001, \#\#P<0.01 compared with negative control } \\
\text { respectively. }\end{array}$
\end{tabular}

The results in Table 6 showed significant increase in time to reach previsited arm of rats treated with $\mathrm{AlCl}_{3}$ when compared to normal control animals. Treatment of rats with ethanolic extract of Picrorhiza kurroa at dose 200, $400 \mathrm{mg} / \mathrm{kg}$ significantly decreased in time to reach previsited arm when compared to negative control rats in dose dependent manner.

\section{Effect of the ethanolic extract of Picrorhiza kurroa (EPK) on brain anti-oxidant status}

The results in Table 7 showed significant decrease in superoxide dismutase, catalase, reduced glutathione and increase in lipid peroxidation of brain homogenate of rats treated with $\mathrm{AlCl}_{3}$ when compared to normal control animals.

Table 7: Effect of ethanolic extract of Picrorhiza kurroa and rivastigmine on oxidative parameters in brain homogenate.

\begin{tabular}{|c|c|c|c|c|}
\hline Group & SOD & CAT & GSH & MDA \\
\hline Normal control & $30.39 \pm 0.743$ & $339.2 \pm 5.093$ & $168.9 \pm 2.620$ & $72.72 \pm 2.41$ \\
\hline Negative control & $20.29 \pm 0.779^{* * *}$ & $145.7 \pm 7.140^{* * * *}$ & $109.0 \pm 1.22^{* * * *}$ & $165.64 \pm 608^{* * * *}$ \\
\hline EPK (200mg/kg) & $22.90 \pm 1.016^{\mathrm{ns}}$ & $300.4 \pm 12.76^{\text {\#\#\# }}$ & $139.4 \pm 1.600^{\# \#}$ & $85.94 \pm 4.81^{\mathrm{ns}}$ \\
\hline EPK (400mg/kg) & $25.08 \pm 0.984^{\# \#}$ & $327.4 \pm 17.0^{\# \#}$ & $159.4 \pm 3.429^{\# \#}$ & $111.1 \pm 3.95^{\# \# \#}$ \\
\hline Rivastigmine & 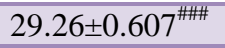 & $327.4 \pm 17.0^{\# \#}$ & $172.7 \pm 5.964^{\mathrm{\# \# \#}}$ & $65.58 \pm 7.33^{\#}$ \\
\hline
\end{tabular}

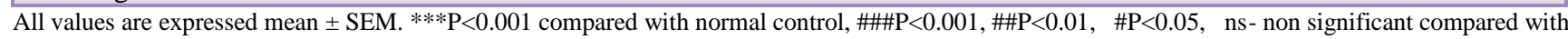
negative control.

Treatment of rats with ethanolic extract of Picrorhiza kurroa at dose $200,400 \mathrm{mg} / \mathrm{kg}$ significantly increased the superoxide dismutase, catalase, reduced glutathione and decreased the lipid peroxidation when compared to negative control rats in dose dependent manner.

\section{Effect of the ethanolic extract of Picrorhiza kurroa (EPK) on brain acetyl cholinesterase content.}

The results in Table 8 showed significant increase in brain acetyl cholinesterase content in rats treated with $\mathrm{AlCl}_{3}$ when compared to normal control animals.
Table 8: Effect of ethanolic extract of Picrorhiza kurroa and rivastigmine on brain acetyl cholinesterase content.

\begin{tabular}{|ll|}
\hline Group & $\begin{array}{l}\text { Acetyl cholinesterase content } \\
(\mu \mathrm{mol} / \mathrm{min} / \mathrm{mg} \text { wet tissue })\end{array}$ \\
\hline Normal control & $15.00 \pm 1.03$ \\
\hline Negative control & $29.00 \pm 2.10^{* * * *}$ \\
\hline EPK $(200 \mathrm{mg} / \mathrm{kg})$ & $19.00 \pm 0.08^{\# \# \#}$ \\
\hline EPK $(400 \mathrm{mg} / \mathrm{kg})$ & $18.15 \pm 0.10^{\# \#}$ \\
\hline Rivastigmine & $16.34 \pm 1.07^{\# \#}$ \\
\hline
\end{tabular}

All values are expressed mean \pm SEM. $* * * \mathrm{P}<0.001$ compared with normal control, \#\# $<0.001$ compared with negative control. 
Treatment of rats with ethanolic extract of Picrorhiza kurroa at dose $200,400 \mathrm{mg} / \mathrm{kg}$ significantly decreased the brain acetyl cholinesterase content when compared to negative control rats in dose dependent manner.

\section{DISCUSSION}

One of the major challenges facing the modern health care system is the neurodegenerative disease such as Alzheimer's disease that represents the most prevalent dementia. $^{26}$ The incidence of Alzheimer's disease increases with age. Anders and Martin mentioned that there were 35.6 million people living with dementia worldwide, which will increase to 65.7 million by 2030 and 115.4 million by 2050 . Aluminium causes oxidative deterioration of cellular lipids, proteins and DNA. Therefore, aluminium can be considered as a contributing factor in $\mathrm{AD} .^{27}$ At present, there is no definitive evidence to support that any particular measure is effective in preventing Alzheimer's disease. ${ }^{28}$ Herbal medicine offers several options to modify the progress and symptoms of Alzheimer's disease. There has been a new trend in the preparation and marketing of drugs based on medicinal plants, and their scientific and commercial significance appears to be gathering momentum in health relevant areas. $^{29-31}$

\section{CONCLUSION}

In the present study we have been tried to investigate the protective and therapeutic effect of Picrorhiza kurroa on Alzheimer's disease. Phenolic substances and flavonoids have been shown to be responsible for antioxidant activity.

The ethanolic extract of Picrorhiza kurroa was found to be having maximum antioxidant activity which may be due to the presence of high amount of flavonoids and moderate amount of phenols. In the present study $\mathrm{AlCl}_{3}$ induced rats showed decrease in locomotor activity, Motor coordination and increase in time taken to climb the pole, increase in transfer of latency in sec, increase in swim latency, increase in time to reach previsited arm when compared to normal rats. Oral administration of ethanolic extract of Picrorhiza kurroa at doses 200, 400 $\mathrm{mg} / \mathrm{kg}$ body weight showed increase in locomotor activity, Motor coordination and decrease in time taken to climb the pole, decrease in Transfer of latency in sec, decrease in swim latency, increase in time to reach previsited arm in a dose dependent manner significantly when compared to $\mathrm{Alcl}_{3}$ induced rats.

Reduction in anti-oxidants like superoxide dismutase, catalase, reduced glutathione and increased levels of malondialdehyde were observed in $\mathrm{AlCl}_{3}$ induced rats significantly when compared to normal control rats. Oral administration of ethanolic extract of Picrorhiza kurroa at doses $200,400 \mathrm{mg} / \mathrm{kg}$ body weight showed increase in superoxide dismutase, catalase, reduced glutathione and decreased levels of malondialdehyde significantly in a dose dependent manner when compared to $\mathrm{AlCl}_{3}$ induced rats. In the present study, results suggest that treatment with ethanolic extract of Picrorhiza kurroa exerted neuroprotective action against $\mathrm{AlCl}_{3}$ induced behavioural parameters and oxidative parameters. Yet, advance studies are needed to characterize the active compound(s) and expose the possible mechanism of action.

\section{ACKNOWLEDGEMENTS}

The authors express sincere thanks to the management of Raghavendra Institute of Pharmaceutical Education and Research (RIPER) for providing necessary chemicals and apparatus.

Funding: No funding sources

Conflict of interest: None declared

Ethical approval: The study was approved by the Institutional Ethics Committee

\section{REFERENCES}

1. Alwakeel AI, Ali AA, Ahmed HI, Abu Elfotuh K, Khalil MG. Comparative study on the influence of epigallocatechin-3-gallate and/or coenzyme Q10 against Alzheimer's disease induced by aluminium in normally-fed and protein malnourished rats. J Alzheimer's Dis Parkinsonism. 2016; 6(3):1-10.

2. Al Mamun A, Wahid F, Sahab Uddin M, Iqbal MA, Rahman MM. Neurodefensive effect of Olea europaea $L$. in alloxan-induced cognitive dysfunction and brain tissue oxidative stress in mice: incredible natural nootropic. J Neurol Neurosci. 2016;7:1-9.

3. Bhattacharya B, Mangilal T, Nagakishore R. Alzheimer's disease-pathophysiology, diagnosis and modern approach of treatment. World J Pharm Pharm Sci. 2014;3(10):1452-60.

4. Wattanathorn J, Uabundit $\mathrm{N}$, Ingkaninan $\mathrm{K}$, Mucimapura S. Cognitive enhancement and neuroprotective effects of Bacopa monnieri in Alzheimer's disease model. J Ethno Pharmacol. 2010;127:26-31.

5. Eidi A, Sarkaki A, Mortazavi P, Hajipour S, Farbood Y, Valizadeh Z. Effect of gallic acid on dementia type of alzheimer disease in rats: electrophysiological and histological studies. Basic Clin Neurosci. 2016;7(2):97-106.

6. Manan A, Malik A, Rasool M, Qureshi MS, Pushparaj PN, Asif M, et al. Recent updates in the treatment of neurodegenerative disorders using natural compounds. eCAM. 2014;2014:1-7.

7. Mahdy KA, Gouda NAM, Marrie AEH, Yassin NAZ, EI-Shenawy SMA, Farrag ARH, Ibrahim BMM. Protective effect of ginger (zingiber officinale) on Alzheimer's disease induced in rats. J Neuroinfect Dis. 2014;5(2):2-10.

8. Rao RV, Descamps O, Varghese J, Bredesen DE. Ayurvedic medicinal plants for Alzheimer's disease: a review. Alzheimers Res Ther. 2012;4(22):2-9. 
9. Kimura R, Ohno M. Impairments in remote memory stabilization precede hippocampal synaptic and cognitive failures in 5XFAD Alzheimer mouse model. Neurobiol Dis. 2009;33:229-35.

10. Beheshti S, Aghaie R. Therapeutic effect of frankincense in a rat model of Alzheimer's disease. Avicenna J Phytomed. 2016;6(4):468-75.

11. Devi KP, Syad AN. Botanics a potential source of new therapies for Alzheimer's disease. Botanics: Targets and Therapy. 2014;4:11-26.

12. Kuboyama T, Tohda C, Komatsu K. Effects of Ashwagandha (roots of Withania somnifera) on neurodegenerative diseases. Biol Pharm Bull. 2014;37(6):892-7.

13. Somesh T, Mahadevan N, Nanjan MJ. Analysis of picroside $\mathrm{i}$ and kutkoside in picrorhiza kurroa and its formulation by HPTLC. Int J Res Pharm Biomed Sci. 2012;3(1):25-30.

14. Katoch M, Fazli IS, Suri KA, Ahuja A, Qazi GN. Effect of altitude on picroside content in core collections of Picrorhiza kurroa from the north western Himalayas. J Nat Med. 2011;65:578-82.

15. Bhandari P, Kumar N, Singh B, Kaul VK. Simultaneous determination of sugar and picrosides in Picrorhiza species using ultrasonic extraction and high performance liquid chromatography with evaporative light scattering detection. J Chromatography A. 2008;1194:257-61.

16. Rajkumar V, Guha G, Kumar RA. Antioxidant and antineoplastic activities of Picrorhiza kurroa extract. Food Chem Toxicol. 2011;49:363-9.

17. Kulkarni S. 1999. Experiment no. 4.4: to study CNS depressant property of chlorpromazine on locomotor activity of mice using actophotometer. Handbook of Experimental Pharmacology. 117-119.

18. Vijitruth R, Liu M, Choi DY. Cyclooxygenase-2 mediates microglial activation and secondary dopaminergic cell death in the mouse MPTP model of Parkinson's disease. J Neuroinflamm. 2006;3:6.

19. Suba V, Murugesan T, Rao RB, Pal M, Mandal SC, Saha BP. Neuropharmacological profile of Barleria lupulina Lindl. extract in animal models. J Ethnopharmacol. 2002;81:251-5.

20. Reddy DS, Kulkarni SK. Possible Role of nitric oxide in the nootropic and antiamnesic effects of neurosteroids on aging- and dizocilpine-induced learning impairment. Brain Res. 1998;799:215-29.
21. Vorhees CV, Williams MT. Morris water maze: procedures for assessing spatial and related forms of learning and memory. Nat Protoc. 2006;1:848-58.

22. Jing H, Yan MC, Jian HW, Yuan YM. Effect of coadministration of morphine and cholinergic antagonists on $\mathrm{Y}$ maze spatial recognition memory retrieval and locomotor activity in mice. Zoological Res. 2008;29:613-20.

23. Makni M, Sefi M, Fetoui H, Garoui MEI, Gargouri N, Boudawara T, Zeghal N. Flax and pumpkin seeds mixture ameliorates diabetic nephropathy in rats. Food Chemical Toxicol. 2010;48:2407-12.

24. Ghanemi A. Alzheimer's disease therapies: Selected advances and future perspectives. Alexandria J Med. 2015;51(1):1-3.

25. Sargazi M, Shenkin A, Roberts NB. Aluminiuminduced injury to kidney proximal tubular cells: Effects on markers of oxidative damage. J Trace Elem Med Biol. 2006;19:267-73.

26. Krishnan S, Cairns R, Howard R. Cannabinoids for the treatment of dementia. The Cochrane database of systematic reviews. 2009;2:CD007204.

27. Abascal K, Yarnell E. Alzheimer's disease. Part 2- A botanical treatment plan. Alternative and Complementary Therapies. 2004;10:67-72.

28. Perry EK, Pickering AT, Wang WW, Houghton PJ, Perry NS. Medicinal plants and Alzheimer's disease: from ethnobotany to phytotherapy. J Pharm Pharmacol. 1999;5:527-34.

29. Howes M.J, Perry NS, Houghton PJ. Plants with traditional uses and activities, relevant to the management of Alzheimer's disease and other cognitive disorders. Phytother Res. 2003;17:1-18.

30. Kennedy DO, Wightman EL. Herbal extracts and phytochemicals: plant secondary metabolites and the enhancement of human brain function. Adv Nutr. 2011;2:32-50.

31. Kumar V. Potential medicinal plants for CNS disorders: an overview. Phytother Res. 2006;20:1023-35.

Cite this article as: Reddy SK, Sudheer A,

Arunamma M, Sree PL, Jyothirmayi E. Protective effect of Picrorhiza kurroa on alzheimer's disease induced by aluminium chloride in rats. Int $\mathrm{J}$ Basic Clin Pharmacol 2017;6:602-7. 